\title{
ДІЯЛЬНІСТЬ ФЕРМЕРСЬКИХ ГОСПОДАРСТВ У ФОРМУВАННІ ПРОПОЗИЦІЇ НА РИНКУ СІЛЬСЬКОГОСПОДАРСЬКОЇ ПРОДУКЦІЇ ТА ВИЗНАЧЕННЯ СТРАТЕГІЧНИХ ПЕРСПЕКТИВ ЇХ РОЗВИТКУ В УКРАЇНІ
}

\author{
ACTIVITIES OF FARMS IN FORMATION OF PROPOSALS \\ ON THE AGRICULTURAL PRODUCTS MARKET \\ AND DETERMINATION OF STRATEGIC PERSPECTIVES \\ OF PROSPECTS IN UKRAINE
}

\author{
Бленда Наталія Олександрівна \\ доктор фрілософрії з економіки, викладач, \\ Уманський національний університет садівництва \\ ORCID: https://orcid.org/0000-0001-7991-4910 \\ Чернега Інна Іванівна \\ доктор економічних наук, доцент, \\ Уманський національний університет садівництва \\ ORCID: https://orcid.org/0000-0001-5573-8617 \\ Коротєєв Микола Анатолійович \\ кандидат економічних наук, доцент, \\ Уманський національний університет садівництва \\ ORCID: https://orcid.org/0000-0001-8739-285X \\ Blenda Nataliia, Cherneha Inna, Korotieiev Mykola
Uman National University of Horticulture
}

\begin{abstract}
В статті досліджено сучасний стан, тенденції розвитку, особливості та проблеми діяльності фрермерських господарств в Україні. Виявлено, що сьогодні в Україні налічується близько 32 тис. фермерських господарств, що становить $67 \%$ від загальної кількості економічно активних сільськогосподарських підприємств. Проте виробничий та соціальний потенціал фрермерських господарств залишається нереалізованим. Встановлено, що незважаючи на значну кількість фермерських господарств, їх частка у загальній структурі виробництва валової продукції сільського господарства $€$ незначною, в межах 9,2\%-11,6\%. Проаналізовано проблеми розвитку фрермерських господарств України та визначено стратегічні перспективи їх розвитку враховуючи міжнародну практику формування ефективної державної аграрної політики.
\end{abstract}

Ключові слова: фрермерські господарства, розвиток, виробництво, ринок сільськогосподарської продукції, стратегічні перспективи, державна підтримка.

В статье исследовано современное состояние, определены тенденции развития, особенности и проблемы деятельности фрермерских хозяйств в Украине. Выявлено, что сегодня в Украине насчитывается около 32 тыс. фермерских хозяйств, что составляет 67\% общего количества экономически активных сельскохозяйственных предприятий. Однако производственный и социальный потенциал фермерских хозяйств остается нереализованным. Установлено, что, несмотря на значительное количество фрермерских хозяйств, их доля в общей структуре производства валовой продукции сельского хозяйства незначительна, в пределах 9,2\%-11,6\%. Проанализированы проблемы развития фермерских хозяйств Украины и определены стратегические перспективы их развития, учитывая международную практику фрормирования эфффективной государственной аграрной политики.

Ключевые слова: фермерские хозяйства, развитие, производство, рынок сельскохозяйственной продукции, стратегические перспективы, государственная поддержка. 
The article examines the current state, development trends, features, and problems of farms in Ukraine. The experience and practice of world agricultural production confirm the high degree of adaptation of farms to market changes, due to the rapid response to changing market conditions, given the flexibility and diversification of production activities. However, today the development of farming in Ukraine is constrained by several problems, the main of which are: lack of working capital and opportunities to attract them, insufficient equipment with modern technical means, instability of state support, and so on. Today in Ukraine there are about 32 thousand farms, which is $67 \%$ of the total number of economically active agricultural enterprises. However, the production and social potential of farms remain unrealized. Despite the significant number of farms, their share in the overall structure of gross agricultural output is insignificant the highest value of this indicator was determined in $2019-11.6 \%$. It is established that the importance of farms in the formation of supply in the market of agricultural products of Ukraine is insignificant, especially comparing the development of farming in Europe. The main problems in the development of Ukrainian farming are lagging behind current trends in the introduction of innovative agricultural technologies. The main reason for this situation is the lack of working capital and the high cost of credit resources. As a result, farms have insufficient material and technical provision. The EU experience provides examples of forming an effective institutional basis for state agricultural policy. The EU's common agricultural policy has significant benefits for European farmers. We are talking about the allocation of subsidies from the multibillion-dollar budget of the European Union to support producers, the application of a simplified system of direct payments, state support in the form of additional payments for young farmers, and the production of certain products. Farms are able to increase production and replenish the supply of agricultural products. Strategic development of farming in Ukraine, aimed at creating competitive farms, should take place under the condition of strengthening the role of state policy to support them and combine it with the development of cooperation and integration.

Keywords: farms, development, production, market of agricultural products, strategic perspectives, state support.

Постановка проблеми. Аграрний сектор економіки України є одним із потужних важелів економічного розвитку. Його виробничий потенціал значно перевищує потреби внутрішнього ринку, що сприяє розвитку національної економіки та підвищенню експортних можливостей країни. В останні роки спостерігаємо тенденцію зростання валютних надходжень саме від реалізації продукції АПК та харчової промисловості на експорт.

Досвід і практика світового аграрного виробництва підтверджує високий ступінь адаптації фрермерських господарств до ринкових змін, за рахунок швидкої реакції на зміну ринкової кон'юнктури враховуючи гнучкість та диверсифікацію виробничої діяльності, що слід розглядати як переваги порівняно із середніми й великими агроформуваннями. Проте, на сьогодні розвиток фермерства в Україні стримується рядом проблем, основними 3 яких є: недостатність власних обігових коштів та можливості їх залучення, недостатня оснащеність сучасними технічними засобами, нестабільність державної підтримки, тощо. Враховуючи, що в економічно розвинених країнах саме фермерство визначено як високоефективна форма аграрного виробництва, проблема розвитку фермерства в Україні на даний час є досить актуальною.

Аналіз останніх досліджень і публікацій. Організаційним, економічним і соціальним аспектам фрункціонування фермерських господарств присвячені праці видатних вітчизняних науковців, таких як: В. Андрійчук, В. Збарський, М. Малік, О. Маслак, В. Месель-Веселяк, П. Саблук, І.В. Свиноус, В.В. Юрчишин та багато інших. Проте, незважаючи на численні дослідження науковців, питання ефрективного та стабільного розвитку, державної підтримки орермерства в Україні залишається актуальним.

Метою статті $€$ дослідження тенденцій розвитку фермерських господарств, їх ролі у формуванні пропозиції на ринку сільськогосподарської продукції, а також визначення стратегічних перспектив та можливостей стимулювання розвитку фермерства в Україні.

Виклад основного матеріалу дослідження. Ринкові трансформації в економіці України вимагали реформування аграрного сектору - на базі колективних сільськогосподарських підприємств сорормувалися нові агроформування засновані на приватній та орендній власності, зокрема фермерські господарства.

Першим законодавчим актом, що регулював правові основи створення та діяльності селянських (фермерських) господарств в Україні був Закон України «Про селянське (фермерське) господарство» № 2009-XII від 20.12.1991 р. прийнятий Верховною Радою України у грудні 1991 р.

На сьогоднішній день правові, економічні та соціальні засади створення та діяльності фермерських господарств як прогресивної форми підприємницької діяльності громадян у галузі сільського господарства України визначає Закон України «Про фермерське господарство» № 973-IV від 19.06.2003 р. Законодавством визначено, що фрермерське господарство $є$ фрормою підприємницької діяльності громадян, які виявили бажання виробляти товарну сільськогосподарську продукцію, здійснювати її переробку та реаліза- 
цію з метою отримання прибутку на земельних ділянках, наданих їм у власність та/або користування, у тому числі в оренду, для ведення фрермерського господарства, товарного сільськогосподарського виробництва, особистого селянського господарства [4].

За визначенням О.С. Дудника [2, с. 93], характерними особливостями орермерських господарств $€$ переважно малі розміри, незначні за обсягом початковий капітал і площі земельних ділянок, опора на власні кошти, орієнтація на кон'юнктуру ринку, зосередження на випуску товарної продукції, комерційний розрахунок, ризик, підприємливість.

За різних причин економічного та політичного характеру впродовж останніх років відбувалось скорочення кількості фрермерських господарств при збільшення площі угідь у їх користуванні. Так, у 2020 р. в Україні кількість фермерських господарств скоротилась на 452 одиниці порівняно із 2015 роком та на 6577 одиниць відносно 2000 року. При цьому площа сільськогосподарських угідь у їх користуванні в 2020 р. збільшилась на 10,9\% та 123,3\% відповідно до 2015 та 2000 років.

На сьогодні в Україні налічується близько 32 тис. фрермерських господарств, що становить
67\% від загальної кількості економічно активних сільськогосподарських підприємств. Найбільша чисельність фрермерських господарств, що здійснювали сільськогосподарську діяльність знаходиться в Дніпропетровській (3115), Миколаївській (3065) та Одеській (3081) областях [10].

Проте виробничий та соціальний потенціал фрермерських господарств залишається нереалізованим. Рівень технічного оснащення, показники ефрективності (зокрема - врожайність) здебільшого $€$ значно нижчими порівняно із середніми та великими підприємствами.

Незважаючи на значну кількість фрермерських господарств, їх частка у загальній структурі виробництва продукції сільського господарства $€$ незначною - найбільше значення даного показника визначено у 2019 р. - 11,6\%. (табл. 1).

За період з 2015 р. по 2020 р. частка фрермерських господарств у загальному виробництві сільськогосподарської продукції незначно збільшилась із 9,2 до 10,7\%, в тому числі: продукції рослинництва 311,5 до 13,2\%, тваринництва - 3 1,9 до 2,5\%. При цьому частка продукції галузі рослинництва в загальному обсязі сільськогосподарської продукції виробленої фрермерськими господарствами становить понад 95\%.

Виробництво сільськогосподарської продукції в постійних цінах 2016 р., млн грн

\begin{tabular}{|c|c|c|c|c|c|c|c|}
\hline Показник & 2015 p. & 2016 p. & 2017 p. & 2018 p. & 2019 p. & 2020 p. & \begin{tabular}{|l}
$2020 \mathrm{p}$ \\
y \% до \\
2015 p.
\end{tabular} \\
\hline \multicolumn{8}{|c|}{ Господарства усіх категорій } \\
\hline $\begin{array}{l}\text { Продукція сільського } \\
\text { господарства }\end{array}$ & 596832,8 & 634433,1 & 620475,6 & 671294,0 & 680982,4 & 612121,5 & 102,6 \\
\hline $\begin{array}{l}\text { в т.ч.: - продукція } \\
\text { рослинництва }\end{array}$ & 453016,9 & 494461,9 & 480157,0 & 529347,5 & 538705,6 & 473377,0 & 104,5 \\
\hline $\begin{array}{l}\text { - продукція } \\
\text { тваринництва }\end{array}$ & 143815,9 & 139971,2 & 140318,6 & 141946,5 & 142276,8 & 138744,5 & 96,5 \\
\hline \multicolumn{8}{|c|}{ Фермерські господарства } \\
\hline $\begin{array}{l}\text { Продукція сільського } \\
\text { господарства }\end{array}$ & 55009,4 & 64306,1 & 63277,2 & 73181,7 & 79053,0 & 65771,8 & 119,6 \\
\hline $\begin{array}{l}\text { в т.ч.: - продукція } \\
\text { рослинництва }\end{array}$ & 52312,9 & 61528,1 & 60491,7 & 70214,1 & 75809,2 & 62295,1 & 119,1 \\
\hline $\begin{array}{l}\text { - продукція } \\
\text { тваринництва }\end{array}$ & 2696,5 & 2778,0 & 2785,5 & 2967,6 & 3243,8 & 3476,7 & 128,9 \\
\hline $\begin{array}{l}\text { Частка фрермерських } \\
\text { господарств } \\
\text { у загальному } \\
\text { виробництві, \%: }\end{array}$ & 9,2 & 10,3 & 10,2 & 10,9 & 11,6 & 10,7 & $+1,5$ вп \\
\hline $\begin{array}{l}\text { в т.ч.: - продукція } \\
\text { рослинництва }\end{array}$ & 11,5 & 12,4 & 12,6 & 13,3 & 14,1 & 13,2 & $+1,7$ вп \\
\hline $\begin{array}{l}\text { - продукція } \\
\text { тваринництва }\end{array}$ & 1,9 & 2,0 & 2,0 & 2,1 & 2,3 & 2,5 & $+0,6$ вп \\
\hline
\end{tabular}


Внесок фрермерських господарств у валове виробництво окремих видів сільськогосподарської продукції $€$ неоднозначним (табл.2).

Аналізуючи дані таблиці 2 визначаємо, що більшість фермерських господарств спеціалізуються на виробництві продукції зернових та соняшнику. Частка продукції зернових і соняшнику виробленої у фрермерських господарствах $€$ досить значною, має загальну тенденцію до зростання (за виключенням 2020 року). Внесок фермерських господарств у виробництво картоплі, овочів, плодів та ягід i, особливо, продукції тваринництва $€$ незначним.

Виробництво значних обсягів трудомісткої сільськогосподарської продукції, зокрема картоплі, овочів, плодів і ягід та молока і меду, зосереджено в особистих господарствах населення, що викликано необхідністю самозабезпечення продуктами харчування, які не потребують промислової переробки. При цьому, господарства населення не тільки забезпечують особисті потреби у продуктах харчування, а й реалізують значну частину виробленої продукції, тобто змінюють натуральну фрорму виробництва на товарну [1, с. 395].

Незважаючи на незначну роль фрермерських господарств у загальному виробництві сільськогосподарської продукції відзначаємо їх важливі соціальні функції. Адже вони забезпечують сільське населення робочими місцями, сприяють розвитку соціальної інорраструктури.

Як бачимо, значення фермерських господарств в аграрному секторі України $€$ незначним, особливо порівнюючи розвиток фрермерства в Європі та США. Основними проблемами розвитку фрермерського господарства України
$€$ відставання від сучасних тенденцій запровадження інноваційних технологій ведення сільського господарства. Основна причина такого становища - брак власних обігових коштів та висока вартість кредитних ресурсів.

Досвід США та ЄС дає приклади фрормування ефрективної інституційної основи державної аграрної політики, забезпечення іï̈ прозорості, передбачуваності, стабільності й гнучкості.

Як зазначає Кириленко [6, с. 7], маючи на старті ті ж проблеми, що й Україна, Польща швидко запровадила передовий досвід, виростила свого одноосібника до потужного фрермера-виробника, що вже дає $65 \%$ усієї сільгосппродукції та більше половини ВВП саме $з$ продажу продовольства. Польща, як i більшість нових країн-учасниць $€ С$, застосовує спрощену систему прямих виплат, а також проводить державну підтримку у вигляді додаткових платежів, серед яких:

- Підтримка для молодих аграріїв. Вона спрямовується молодим (до 40 років) людям, які тільки почали працювати у сільському господарстві, або тим, які вже мають нещодавно започатковану (до 5 років) власну невеличку аграрну справу.

- Підтримка виробника. Кошти надаються господарствам, які вирощують або виробляють певні види продукції, наприклад: рис, гречку, молоко та молочні продукти, насіння, телятину, оливкову олію, хміль, цикорій, фррукти, овочі й ін.

- Підтримка для дрібних господарств. Невелика для Євросоюзу сума до 1250 євро стимулює розвиток мікроферм.

Польські аграрії, як і німецькі, також можуть розраховувати на допомогу від держави і за

Частка фрермерських господарств у загальному виробництві

Таблиця 2 основних видів продукції, \%

\begin{tabular}{|l|c|c|c|c|c|c|c|}
\hline \multicolumn{1}{|c|}{ Показник } & $\mathbf{2 0 1 5}$ p. & $\mathbf{2 0 1 6}$ p. & $\mathbf{2 0 1 7}$ p. & $\mathbf{2 0 1 8}$ p. & $\mathbf{2 0 1 9}$ p. & $\mathbf{2 0 2 0}$ p. & $\begin{array}{c}\mathbf{2 0 2 0} \text { p. } \\
\mathbf{+ , -} \text { до } \\
\mathbf{2 0 1 5} \mathbf{p .}\end{array}$ \\
\hline $\begin{array}{l}\text { Зернові та } \\
\text { зернобобові культури }\end{array}$ & 12,7 & 13,4 & 14,0 & 14,4 & 15,3 & 14,9 & $+2,2$ \\
\hline Буряк цукровий & 6,0 & 6,9 & 7,4 & 6,9 & 4,5 & 4,6 & $-1,4$ \\
\hline Соняшник & 19,4 & 19,4 & 19,3 & 19,8 & 20,3 & 18,8 & $-0,6$ \\
\hline Картопля & 0,6 & 0,6 & 0,5 & 0,5 & 0,5 & 0,5 & $-0,1$ \\
\hline Овочі & 3,1 & 3,2 & 2,9 & 2,7 & 3,0 & 3,0 & $-0,1$ \\
\hline Плоди та ягоди & 3,2 & 4,8 & 3,7 & 5,3 & 4,7 & 4,5 & $+1,3$ \\
\hline М'ясо (у забійній масі) & 2,3 & 2,4 & 2,5 & 2,5 & 2,8 & 3,1 & $+0,8$ \\
\hline Молоко & 1,7 & 1,8 & 1,9 & 2,0 & 2,2 & 2,4 & $+0,7$ \\
\hline Яйця & 0,4 & 0,6 & 0,6 & 0,7 & 0,8 & 0,8 & $+0,4$ \\
\hline
\end{tabular}


завдану шкоду в результаті стихійних лиха чи інших зовнішніх фракторів [13].

Основними напрямками забезпечення продовольчої безпеки США є програма підтримки орермерів «Стабілізація доходів фермерів», до іiї складу входять програми: «Державна програма підтримки цін», «Страхування врожаю», «Сільськогосподарський кредит». Рівень підтримки аграрних цін сягає 50\%, а 21\% доходів фермерів складають прямі субсидії держави. Окрім того, значні обсяги фрінансових ресурсів у США спрямовуються на закупівлю надлишків сільськогосподарської продукції у фермерів 3 метою утримання закупівельних цін і гарантування дохідності виробників сільськогосподарської продукції [5].

3 метою стимулювання розвитку фермерства та спрощення ведення бізнесу 31 березня 2016 року Верховна Рада України прийняла Закон «Про внесення змін до Закону України «Про фрермерське господарство» щодо створення та діяльності сімейних фрермерських господарств (Голос України. 2016. № 80 від 30 квітня), який набув чинності 31 травня 2016 року. Відповідно до Закону фрермерські господарства можуть створюватися й діяти в двох організаційно-правових фоормах: 1) як юридична особа або 2) як фрізична особа підприємець [3]. Ведення фрермерського господарства як ФОП (без створення юридичної особи) істотно спрощує процес реєстрації та здійснення господарської діяльності фрізичної особи-срермера.

Як підтримку розвитку фрермерства в Україні, у 2017 році Урядом було затверджено Концепцію розвитку фрермерських господарств та сільськогосподарської кооперації на 2018-2020 рр., спрямовану виключно на підтримку фермерських господарств із площею не більше 100 гектарів. Такий підхід мав би охопити державною фрінансовою підтримкою близько $70 \%$ загальної кількості фрермерських господарств [7].

Слід зазначити, що у 2021 р. рівень державних видатків на підтримку аграрного сектору України склав 4665 млн. грн, з них лише 120,79 млн. грн виділено на програму фрінансової підтримки розвитку фрермерських господарств, що становить 2,6\% загальної суми фрінансової підтримки сільськогосподарських товаровиробників [11].

Погоджуючись 3 думкою Олександра Маслака [8] зазначимо, що в ринкових умовах дрібним фрермерським господарствам складно конкурувати на розвинених аграрних ринках, до яких належить ринок зерна та олій- ного насіння. Фермери мають невеликі товарні партії продукції, не поодинокі випадки реалізації продукції з поля, без необхідної доробки та доведення до вимог державних стандартів. Тож ціна на таку продукцію $€$ значно нижчою від існуючої на ринку, що відображається на кінцевих результатах діяльності.

Враховуючи, зазначені проблеми срункціонування фрермерських господарств в Україні, їх стратегічний розвиток має відбуватись на умовах інтеграції (вертикальної або горизонтальної) та кооперування, що дозволить вирішити ряд проблем виробничого та маркетингового характеру щодо ресурсного забезпечення, зниження витрат і підвищення ефрективності діяльності фрермерських господарств. Така стратегія забезпечить створення конкурентоспроможних об'єднань, здатних в ринкових умовах конкурувати з великими підприємствами та агрохолдингами.

3 масовою організацією фрермерських (селянських) господарств аграрна економіка стане антимонопольною та конкурентоздатною. Фермерські господарства спроможні збільшити виробництво і поповнити торгівлю продуктами харчування і тим самим зробити вагомий внесок у вирішення національної продовольчої проблеми. Для українських фрермерів також мають бути створені сприятливі умови для розвитку бізнесу. Розвиток фермерства має стати основою відродження українського села, основою для прискорення економічного зростання в країні. Саме на це мають бути спрямовані зусилля уряду [14].

Висновки. Фермерські господарства разом з особистими селянськими господарствами в Україні належать до малого бізнесу. Фермерські господарства виконують і важливу соціальну фуункцію та можуть суттєво впливати на соціальну інфраструктуру сільських територій.

За умови вирішення матеріальних та організаційних проблем фрермерські господарства здатні значно підвищити свою ефективність та зробити більш значний внесок в наповнення ринку сільськогосподарської продукції і, відповідно, підвищення продовольчого забезпечення.

Стратегічний розвиток фрермерства в Україні, що має на меті створення конкурентоздатних фрермерських господарств, має відбуватись за умови посилення ролі державної політики щодо їх підтримки та поєднання ії 3 розвитком кооперації та інтеграції, забезпечуючи концентрацію виробництва та конкурентоспроможність аграрної продукції як на вітчизняних, так і зарубіжних ринках. 


\section{СПИСОК ВИКОРИСТАНИХ ДЖЕРЕЛ:}

1. Бленда Н.О. Стан та перспективи виробництва продукції тваринництва особистими селянськими господарствами на Черкащині. Збірник наукових праць УДАУ. Умань, 2007. Вип. 64. Ч. 2: Економіка. С. 393-399.

2. Дудник О.С. Перспективи розвитку фермерства в Україні. Економіка АПК. 2016. № 3. С. 92-97.

3. Закон «Про внесення змін до Закону України «Про фермерське господарство» № 1067-VIII від 31.03.2016. URL: http://zakon5.rada.gov.ua/laws/show/1067-19

4. Закон України «Про фрермерське господарство» № 973-IV від 19.06.2003 p. URL: http://zakon3.rada.gov.ua/ laws/show/973-15

5. Калабеков И. Россия, Китай и США в цифррах. URL: http://kaig.ru/outthrow.pdf

6. Кириленко І.Г., Івченко В.Є. Структурні ресорми на селі: світовий досвід, українські реалії. Економіка АПК. 2016. № 2. С. 5-11.

7. Концепція розвитку фрермерських господарств та сільськогосподарської кооперації на 2018-2020 роки. URL http://zakon2.rada.gov.ua/laws/show/ru/664-2017-\%D1\%80\#n8

8. Маслак О. Проблеми та перспективи фрермерства в Україні. Агробізнес Сьогодні. 2015. URL: http://agro-business.com.ua/agro/ekonomichnyi-hektar/item/7914-problemy-ta-perspektyvy-fermerstva-v-ukraini.html

9. Розвиток фермерства та кооперації. Урядовий портал. URL: https://www.kmu.gov.ua/ua/diyalnist/reformi/ rozvitok-fermerstva-ta-kooperaciyi

10. Сільське господарство України за 2020 рік : статистичний збірник. Державна служба статистики України, 2021. URL: http://www.ukrstat.gov.ua/druk/publicat/kat_u/2021/zb/09/zb_sg_20.pdf

11. Фінансування з Державного бюджету. Стан фрінансування АПК у 2021 році. Міністерство аграрної політики та продовольства України. URL: https://minagro.gov.ua/ua/napryamki/finansova-politika/finansuvannya-zderzhavnogo-byudzhetu/stan-finansuvannya-apk-u-2021-roci

12. Як держава стимулюватиме розвиток фрермерства URL: https://agroreview.com/news/yak-derzhavastymulyuvatyme-rozvytok-fermerstva

13. Як живеться фрермерам в Європі? Пільги кредити й нові ринки. Укрінфрорм. URL: https://www.ukrinform.ua/ rubric-economy/2320798-ak-zivetsa-fermeru-v-evropi-pilgi-krediti-j-novi-rinki.html

14. GоЗаАгроДотаціями: Як «розпиляли» 6,3 млрд грн бюджетних коштів у 2018 році. URL: https://agropolit.com/spetsproekty/533-gozaagrodotatsiyami-vipusk-4-2018---yak-rozpilyali-63-mlrd-grn

\section{REFERENCES:}

1. Blenda N.A. (2007) Status and prospects of livestock production by private farms in Cherkasy region. Collection of scientific works of UDAU. Uman, 64, part. 2: Economics, pp. 393-399.

2. Dudnyk O.S. (2016) Prospects for the development of farming in Ukraine. Economics of agro-industrial complex, no. 3, pp. 92-97.

3. Law "On Amendments to the Law of Ukraine" On Farming № 1067-VIII of March 31, 2016. Retrieved from: http://zakon5.rada.gov.ua/laws/show/1067-19

4. Law of Ukraine "On Farming" № 973-IV of 19.06.2003. Retrieved from: http://zakon.rada.gov.ua/go/973-15

5. Kalabekov I. Russia, China and the USA in numbers. Retrieved from: http://kaig.ru/outthrow.pdf

6. Kyrylenko I.G., Ivchenko V.Ye. (2016) Structural reforms in rural areas: world experience, Ukrainian realities. Economics of agro-industrial complex, no. 2, pp. 5-11.

7. The concept of development of farms and agricultural cooperation for 2018-2020. Retrieved from: https://zakon.rada.gov.ua/laws/show/ru/664-2017-p\#Text

8. Maslak O. (2015) Problems and prospects of farming in Ukraine. Agribusiness Today. Retrieved from: http://agro-business.com.ua/agro/ekonomichnyi-hektar/item/7914-problemy-ta-perspektyvy-fermerstva-v-ukraini.html

9. Development of farming and cooperation. Government portal site. Retrieved from: https://www.kmu.gov.ua/ ua/diyalnist/reformi/rozvitok-fermerstva-ta-kooperaciyi

10. Agriculture of Ukraine for 2020: statistical collection. State Statistics Service of Ukraine, 2021. Retrieved from: http://www.ukrstat.gov.ua/druk/publicat/kat_u/2021/zb/09/zb_sg_20.pdf

11. Financing from the State budget. The state of agro-industrial complex financing in 2021. Ministry of Agrarian Policy and Food of Ukraine. Retrieved from: https://minagro.gov.ua/ua/napryamki/finansova-politika/finansuvannya-z-derzhavnogo-byudzhetu/stan-finansuvannya-apk-u-2021-roci

12. How the state will stimulate the development of farming. Retrieved from: https://agroreview.com/news/ yak-derzhava-stymulyuvatyme-rozvytok-fermerstva

13. How do farmers live in Europe? Benefits loans and new markets. Ukrinform. Retrieved from: https://www.ukrinform.ua/rubric-economy/2320798-ak-zivetsa-fermeru-v-evropi-pilgi-krediti-j-novi-rinki.html

14. GoZaAhroDotatsiyamy: How to "saw" 6.3 billion UAH of budget funds in 2018. Retrieved from: https://agropolit.com/spetsproekty/533-gozaagrodotatsiyami-vipusk-4-2018---yak-rozpilyali-63-mlrd-grn 